\title{
Strength Characteristics of Concrete with Waste Polypropylene as Modifier for Pavement Construction
}

\author{
Olugbenga Joseph Oyedepo ${ }^{1}$, Ebenezer Omoniyi Olukanni ${ }^{1 \bowtie \bowtie}$ and Temitope Rufai Arowolo $^{2}$ \\ ${ }^{I}$ Department of Civil Engineering, Federal University of Technology, P.M.B, 704, Akure, Ondo State, Nigeria \\ ${ }^{2}$ Datoch Properties and Engineering Limited, 140/142 Liberty Road, Ibadan, Nigeria \\ ${ }^{\star}$ Corresponding author’s Email: oeolukanni@futa.edu.ng; (DORCiD: 0000-0002-6086-5888
}

\begin{abstract}
The demand for a better performing pavement and the need to convert the ever-growing polymer waste into beneficial use necessitated the need to develop and characterize a polypropylene modified concrete for use in pavement construction. This research focuses on characterizing the strength of concrete produced with waste polypropylene waste as modifiers for pavement construction. The materials used in this research are fine and coarse aggregates, cement and polypropylene waste chairs (PWC). Tests were performed on the aggregate and fresh concrete to determine their suitability and characteristics for use in concrete for pavement. Two concrete grades 1:2:4 and 1:3:6 was produced into $200 \mathrm{~mm}, 400 \mathrm{~mm}$ and $500 \mathrm{~mm}$ long paving stones on which compressive and

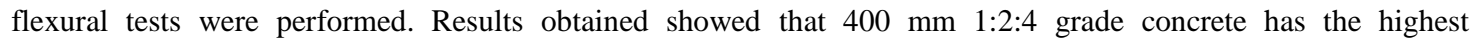

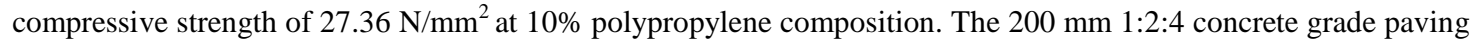
stone with $10 \%$ polyprpopylene composition has the highest flexural strength of $12.90 \mathrm{~N} / \mathrm{mm}^{2}$. The $200 \mathrm{~mm}$ at $10 \%$ polypropylene composition correlation coefficient has that the highest value of 0.98 which better explains the compression-flexural strength relationship and validates the $200 \mathrm{~mm}$ length at $10 \%$ polypropylene composition paving stone as the most adequate length of paving stone for pavement construction. It was concluded that the 200 mm long 1:2:4 concrete grade paving stone at $10 \%$ polypropylene composition is the best length of paving stone that can give an adequate flexural strength which is the most important requirent in concrete pavement requirement.
\end{abstract}

Keywords: Waste Polypropylene, Concrete, Compressive Strength, Flexural Strength, Paving Stones, Pavement

\section{INTRODUCTION}

One of the solid wastes generated in large quantities and being of a high threat to the sustainability of our planet is plastic wastes. It has been reported that damage occurs to ecology, economy, and aesthetics when plastic debris enters into oceans (Jambeck, et al., 2018). Singh and Sharma (2016) confirmed that about 300 million metric tons of plastic wastes have been estimated to be generated annually worldwide. A report by the Environmental Protection Agency (EPA, 2015) has shown that out of several tons of plastic wastes generated annually, only $7 \%$ is recycled, about $8 \%$ incinerated and the remaining are landfilled. Lazarevic et al. (2010) postulated that the low biodegradability of plastic poses a huge limitation on its recyclability and disposal into the environment. Furthermore, the prospects and retrospects of the use of plastic in flexible pavements was studied by Bhardwaj et al. (2020) and Saberian et al. (2021) conducted a resrach on repurposing of COVID-19 single-use face masks for pavements base/subbase. The study revealed that introduction of the shredded face mask not only increased the strength and stiffness but also improved the ductility and flexibility of recycled concrete aggregate and shredded face mask blends.

In recent years, studies have focused concrete production with waste glass, recycled crushed glass, steel slag, steel fiber, tyres and plastics eliminate plastic's disposal problems and develop the mechanical features of concrete (Shah and Pitroda, 2013). However, due to the lack of superior strength and durability in conventional concrete pavement, material engineering has focused on its physical, structural and mechanical features development. Also, considering the concrete pavement's voids and porosity (Ramadhansyah et al., 2014), obtaining great strength through ordinary materials and their mixtures is almost impossible. Consequently, adding materials such as admixture and superplasticizer cement or aggregates replacements besides few waste materials and Nano-materials have been applied to increase the 
properties of concrete used in pavement (Huang et al., 2007). Therefore, finding applications where plastic wastes are useful will proffer a sustainable way to its management.

\section{MATERIALS AND METHODS}

\section{Materials}

The materials used for this research work were of high quality and were carefully selected and sourced locally in Akure, Nigeria to meet standard requirements. The materials are:

i. Fine aggregates: Fine aggregates are natural sand or crushed stone that are less than $5 \mathrm{~mm}$ in diameter. The fine aggregate is crushed grave, rock sand blended sand and fines which mainly passes through a $5.0 \mathrm{~mm}$ BS 410 sieve and containing no more coarser material than is permitted for the various gradings in the specifications for aggregates from natural sources for concrete (BS EN 12620:2002+A1:2008).

ii. Coarse aggregates: Coarse aggregates are naturally occurring uncrushed, crushed or partially crushed gravel that are less than $5 \mathrm{~mm}$ in diameter. The coarse aggregate is mainly retained on a $5.0 \mathrm{~mm}$ BS 410 sieve and containing no more finer material than is permitted for the various sizes in the specifications for aggregates $\mathrm{s}$ for concrete (BS EN 12620:2002+A1:2008).

iii. Ordinary Portland Cement: Cement is a hydraulic binder, it is a finely ground inorganic material which when mixed with water, forms a paste which sets and harden by means of hydration reactions and processes and which, after hardening, retains its strength and stability even under water according to composition, specification and conformity criteria for common cement (BS EN 197-1: 2011).

iv. Waste Polypropylene chair: The waste polypropylene chair or waste polyprop is a waste of a chair manufactured in an injection moulding process using polypropylene, it is a plastic polymer of the chemical designation $\mathrm{C}_{3} \mathrm{H}_{6}$.

\section{Sample preparation}

Polypropylene based plastic waste chair was pulverized with ball milling machine, it was then sieved with a $0.075 \mu \mathrm{mm}$ sieve, this was used as an additive in concrete in this research work. Paving stones of varying lengths of $200 \mathrm{~mm}, 400 \mathrm{~mm}$ and $500 \mathrm{~mm}$ were produced with polypropylene wastes chair (PWC) added in varying proportion of $2 \%, 4 \%, 6 \%, 8 \%$ and $10 \%$ by weight. The paving stones were produced using 1:2:4 and 1:3:6 concrete mix ratios, for each percentage replacement and concrete grades, three samples were produced to test for flexural and compressive tests. The paving stones were cured for 7, 14, 21 and 28 days before they were tested for compression and flexure. Table 1 contains the mix ratios, percentage polypropylene waste chair content, mix ratios, number of curing days and the total number of paving stones produced for flexural and compressive tests. A total of 720 paving stones were produced.

Table 1. PWC Composition, paving stone (PS) sizes, concrete grades and number of PS produced

\begin{tabular}{|c|c|c|c|c|c|c|c|c|c|c|}
\hline \multirow{2}{*}{ PWC (\%)/ Days } & \multirow{2}{*}{ Paving Stone Sizes } & \multicolumn{4}{|c|}{$1: 2: 4$} & \multicolumn{4}{|c|}{$1: 3: 6$} & \multirow[b]{2}{*}{ Total } \\
\hline & & 7 & 14 & 21 & 28 & 7 & 14 & 21 & 28 & \\
\hline 2 & \multirow{5}{*}{$200 \times 100 \times 100$} & 6 & 6 & 6 & 6 & 6 & 6 & 6 & 6 & \multirow{5}{*}{240} \\
\hline 4 & & 6 & 6 & 6 & 6 & 6 & 6 & 6 & 6 & \\
\hline 6 & & 6 & 6 & 6 & 6 & 6 & 6 & 6 & 6 & \\
\hline 8 & & 6 & 6 & 6 & 6 & 6 & 6 & 6 & 6 & \\
\hline 10 & & 6 & 6 & 6 & 6 & 6 & 6 & 6 & 6 & \\
\hline 2 & \multirow{5}{*}{$400 \times 100 \times 100$} & 6 & 6 & 6 & 6 & 6 & 6 & 6 & 6 & \multirow{5}{*}{240} \\
\hline 4 & & 6 & 6 & 6 & 6 & 6 & 6 & 6 & 6 & \\
\hline 6 & & 6 & 6 & 6 & 6 & 6 & 6 & 6 & 6 & \\
\hline 8 & & 6 & 6 & 6 & 6 & 6 & 6 & 6 & 6 & \\
\hline 10 & & 6 & 6 & 6 & 6 & 6 & 6 & 6 & 6 & \\
\hline 2 & \multirow{5}{*}{$500 \times 100 \times 100$} & 6 & 6 & 6 & 6 & 6 & 6 & 6 & 6 & \multirow{5}{*}{240} \\
\hline 4 & & 6 & 6 & 6 & 6 & 6 & 6 & 6 & 6 & \\
\hline 6 & & 6 & 6 & 6 & 6 & 6 & 6 & 6 & 6 & \\
\hline 8 & & 6 & 6 & 6 & 6 & 6 & 6 & 6 & 6 & \\
\hline 10 & & 6 & 6 & 6 & 6 & 6 & 6 & 6 & 6 & \\
\hline
\end{tabular}




\section{Method}

Physical properties. The physical properties of aggregates used in this research work were determined and confirmed suitable for production of concrete for paving stones by carrying out the following tests:

i. Aggregate Impact Value test (BS EN 1097-2:2020)

ii. Aggregate Crushing Value test (BS EN 10972:2020)

iii. Moisture content Test (BS 812-109:1990)

iv. Particle size distribution test (BS ISO 11277:2020)

Properties of fresh concrete. The properties of fresh concrete produced for casting of the paving stone were investigated by conducting the following tests:

i. Slump test (BS EN 12350-2:2019)

ii. Compacting factor test (BS EN 12350-4:2019)

The strength properties of hardened concrete were investigated by performing the following tests:

i. Compressive test (BS EN 12390-3:2019)

ii. Flexural test (BS EN 12390-5:2019)

\section{RESULT AND DISCUSSION}

\section{Aggregate crushing value (ACV)}

The result of aggregate crushing value (ACV) test carried out on the coarse aggregate used in this research work is presented in Table 2, it can be seen that the average ACV value obtained is $27.71 \%$. This indicates that shows that aggregates are strong enough to withstand crushing due to rolling and traffic loads.

\section{Aggregate impact value (AIV)}

The result of aggregate impact value (AIV) test carried out on the coarse aggregate to determine its toughness is presented in Table 3. It can be seen that the average AIV value obtained is $20.24 \%$ which is a good measure of toughness and resistance against any impact load.

\section{Particle size distribution}

This test was performed to determine the particle grading of the fine aggregates used in this research. Figure 1 shows the plot of the particle grading curve of the fine aggregated used. From the result, it can be the seen that the soil is well graded.

\section{Moisture content}

The moisture content test result performed on the fine aggregate in Table 4 showed that the average moisture is $2.75 \%$ which is within the tolerable maximum limit of $5 \%$.

\section{Slump test}

The result of slump test conducted on the 1:2:4 and 1:3:6 concrete grades with $0-10 \%$ polypropylene composition to determine their consistencies are presented in Table 5. The slump values obtained as shown in Table 4, the slump values are less than $100 \mathrm{~mm}$ maximum slump values required for concrete for road pavements.

Table 2. Aggregate crushing value (ACV) of coarse aggregate

\begin{tabular}{lccc}
\cline { 2 - 4 } & Sample 1 & Sample 2 & Sample 3 \\
\hline Weight of sample before Test $(\mathrm{kg})$ & 536.30 & 541.30 & 529.20 \\
\hline Weight of sample after Test $(\mathrm{kg})$ & 145.30 & 152.30 & 147.70 \\
\hline ACV $(\%)$ & 27.09 & 28.14 & 27.91 \\
\hline Average ACV (\%) & & 27.71 & \\
\hline
\end{tabular}

Table 3. Aggregate impact value (ACV) of coarse aggregate

\begin{tabular}{lccc}
\cline { 2 - 4 } & Sample 1 & Sample 2 & Sample 3 \\
\hline Weight of sample before Test $(\mathrm{kg})$ & 437.20 & 425.00 & 440.30 \\
\hline Weight of sample after Test $(\mathrm{kg})$ & 85.20 & 87.30 & 91.10 \\
\hline ACV $(\%)$ & 19.49 & 20.54 & 20.69 \\
\hline Average ACV $(\%)$ & & 20.24 & \\
\hline
\end{tabular}

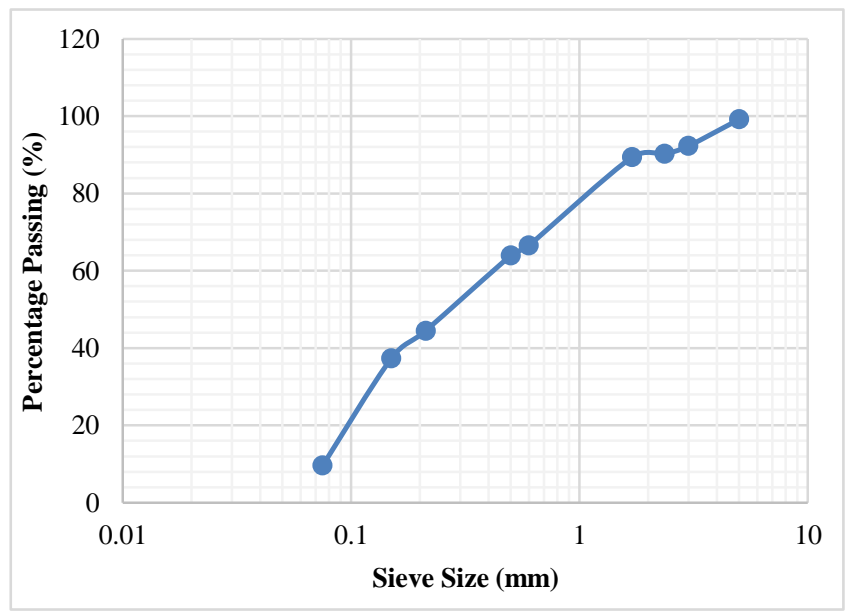

Figure 1. Particle grading of fine aggregate curve

Table 4. Moisture content of fine aggregate

Sample 1 Sample 2 Sample 3

\begin{tabular}{lccc}
\hline Wt of Can & 4.80 & 4.80 & 4.80 \\
Wt of Can + Wet Sample (g) & 57.30 & 63.30 & 55.20 \\
\hline Wt of Wet Sample (g) & 52.50 & 58.50 & 50.40 \\
\hline Wt of Can + Dry Sample (g) & 56.80 & 63.10 & 54.80 \\
\hline Wt of Dry Sample (g) & 52.00 & 58.30 & 49.30 \\
\hline Moisture Content (\%) & 0.96 & 0.34 & 0.80 \\
\hline Average Moisture Content (\%) & \multicolumn{3}{c}{0.70} \\
\hline
\end{tabular}


The average moisture content of $0.70 \%$ is very small, therefore water has no effect on the quality of the concrete produced.

Table 5. Slump values of concrete grades 1:2:4 and 1:3:6

\begin{tabular}{lcc}
\hline $\begin{array}{l}\text { Polypropylene } \\
\text { Composition }\end{array}$ & $\begin{array}{c}\text { 1:2:4 Concrete } \\
\text { Grade }\end{array}$ & $\begin{array}{c}\mathbf{1 : 3 : 6 ~ C o n c r e t e ~} \\
\text { Grade }\end{array}$ \\
\cline { 2 - 3 }$\left(\begin{array}{c}\text { Slump }(\mathbf{m m}) \\
\hline 0\end{array}\right.$ & 19.00 & Slump $(\mathbf{m m})$ \\
\hline & 18.50 & 65.00 \\
4 & 16.00 & 70.00 \\
6 & 15.50 & 70.00 \\
8 & 14.00 & 72.00 \\
10 & 9.50 & 75.00 \\
\hline
\end{tabular}

The slump values obtained are less than $50 \mathrm{~mm}$ maximum slump values required for concrete for road pavements.

\section{Compacting factor test}

The result of compacting factor test conducted on the 1:2:4 and 1:3:6 concrete grades with $0-10 \%$ poly propylene composition to determine their workability are presented in Table 6. The compacting factors obtained indicated that they are all more than 0.95 which is the minimum requirement for a good compacting factor.

\section{Compressive strength for 1:2:4 paving stone}

Concrete road pavements are usually specified and designed using the characteristic compressive strength at 28 days. This refers to the strength value which $95 \%$ of samples will exceed after 28 days curing in laboratory conditions. The compressive strength is not important for road pavement design, but is used as a proxy for flexural strength. For this reason, characteristic 28-day compressive strength of the concrete is used along with a defined relationship between compressive strength and flexural strength for this particular concrete mix. The compressive strength for $200 \mathrm{~mm}, 400 \mathrm{~mm}$ and $500 \mathrm{~mm}$ paving stone with concrete grade 1:2:4 is presented in Tables 7 - 9.

The result showed an increasing trend in the compressive strengths of the paving stones from 7 days to 28 days for all the percentage compositions. $10 \%$ polypropylene composition has $26.03 \mathrm{~N} / \mathrm{mm}^{2}$ which is the highest at 28 days. Compressive strength requirements for paving concrete are generally specified at $20.7 \mathrm{MPa}(3,000$ psi) at 28 days in BS EN 1338:2013. The repair concrete should develop an equal or greater strength by the time it receives traffic loadings. The result showed an increasing trend in the compressive strengths of the paving stones from 7 days to 28 days for all the percentage compositions. $10 \%$ polypropylene composition has 26.03 $\mathrm{N} / \mathrm{mm}^{2}$ which is the highest at 28 days. The result meets the requirement on the strength to be attained at 28 days before a concrete pavement is opened to traffic.
The highest compressive strength for $400 \mathrm{~mm}$ paving stone is $27.36 \mathrm{~N} / \mathrm{mm}^{2}$ obtained in 28 days at $10 \%$ polypropylene composition; this value meets the compressive strength requirement for concrete pavement at 28 days. Furthermore, the $500 \mathrm{~mm} \mathrm{1:2:4} \mathrm{paving} \mathrm{stone}$ has its compressive strength increasing with increase in the age of the concrete as presented in Table 3. The highest compressive strength of $26.27 \mathrm{~N} / \mathrm{mm}^{2}$ for $500 \mathrm{~mm}$ 1:2:4 concrete was obtained after 28 days of curing. The result meets the minimum requirement of $20 \mathrm{~N} / \mathrm{mm}^{2}$ for concrete pavement.

\section{Compressive strength for 1:3:6 paving stone}

The 28 days compressive strength for $200 \mathrm{~mm}, 400$ $\mathrm{mm}$ and $500 \mathrm{~mm}$ paving stone with concrete grade 1:3:6 is presented in Table 10. The compressive strength of 200

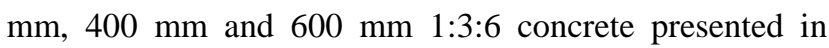
Table 4 showed that none of length of the paving stones meets minimum requirement of $20 \mathrm{~N} / \mathrm{mm}^{2}$ for 28 days to open the concrete pavement for traffic.

\section{Flexural strength of paving stones}

The flexural strength also known as the modulus of rupture is a measure of the tensile strength of concrete. It is a measure of an unreinforced concrete beam or slab to resist failure in bending. Concrete pavements are currently designed using a mean 28-day flexural strength of 4.5 $\mathrm{N} / \mathrm{mm}^{2}(650 \mathrm{psi})$ based on the third point loading and a flexural strength of $4.1 \mathrm{~N} / \mathrm{mm}^{2}$ (600 psi) is required to open pavement to traffic prior to 14 days after placement according to the concrete paving blocks requirements and test method (BS EN 1338:2003). - 21). The 14 days flexural strength test result of $200 \mathrm{~mm}, 400 \mathrm{~mm}$ and 500 $\mathrm{mm}$ long 1:3:6 paving stones with varying polypropylene composition used in this research is presented in Table 11.

It can be seen from the result that the 14 days flexural strength criteria of $4.1 \mathrm{~N} / \mathrm{mm}^{2}$ (600 psi) required to open pavement to traffic is met by all the paving stone lengths from 0 to $10 \%$ polypropylene composition; the highest flexural strength of $7.50 \mathrm{~N} / \mathrm{mm}^{2}$ was obtained after 14 days at $10 \%$ polypropylene composition for $200 \mathrm{~mm}$ length. The 28 days flexural strength test result of 200 $\mathrm{mm}, 400 \mathrm{~mm}$ and $500 \mathrm{~mm}$ long 1:3:6 paving stones with varying polypropylene composition used in this research is presented in Table 12.

The result showed that the $200 \mathrm{~mm}$ long paving stone with $10 \%$ polyprpopylene composition has the highest flexural strength of $12.90 \mathrm{~N} / \mathrm{mm}^{2}$ which meets the flexural strength design critreria of mean 28-day flexural strength of $4.5 \mathrm{~N} / \mathrm{mm}^{2}$. Other percentage compositions and lengths of $200 \mathrm{~mm}, 400 \mathrm{~mm}$ and $600 \mathrm{~mm}$ also meet the criteria. 
Oyedepo et al., 2021

Table 6. Compacting factor of concrete grades 1:2:4 and 1:3:6

\begin{tabular}{lcccccc}
\hline \multirow{2}{*}{$\begin{array}{l}\text { Polypropylene } \\
\text { Composition (\%) }\end{array}$} & \multicolumn{3}{c}{$\mathbf{1 : 2 : 4}$ Concrete Grade } & \multicolumn{2}{c}{ 1:3:6 Concrete Grade } \\
\cline { 2 - 6 } & Full & Part & Compacting Factor & Full & Part & Compacting Factor \\
\hline 0 & 18.0 & 17.60 & 0.98 & 17.80 & 17.50 & 0.98 \\
2 & 17.70 & 17.10 & 0.97 & 18.10 & 17.80 & 0.98 \\
4 & 18.20 & 17.00 & 0.93 & 17.80 & 17.30 & 0.97 \\
6 & 18.20 & 17.10 & 0.94 & 17.90 & 17.20 & 0.96 \\
8 & 18.30 & 17.50 & 0.96 & 18.00 & 17.60 & 0.97 \\
10 & 18.30 & 17.80 & 0.97 & 17.90 & 17.20 & 0.96 \\
\hline
\end{tabular}

Table 7. Compressive strength for $200 \mathrm{~mm}$ paving stone

\begin{tabular}{lcccc}
\hline \multirow{2}{*}{$\begin{array}{l}\text { Polypropylene } \\
\text { Composition (\%) }\end{array}$} & \multicolumn{4}{c}{ Compressive Strengths $\left(\mathbf{N} / \mathbf{m m}^{\mathbf{2}}\right)$} \\
\cline { 2 - 5 } 10 & $\mathbf{7}$ days & 14 Days & 21 Days & 16.13 \\
8 & 9.87 & 12.50 & 14.90 & 26.03 \\
6 & 9.30 & 12.43 & 13.30 & 25.80 \\
4 & 9.30 & 11.40 & 13.57 & 24.87 \\
2 & 8.37 & 11.50 & 13.00 & 24.45 \\
0 & 7.97 & 11.43 & 12.70 & 24.25 \\
\hline
\end{tabular}

Table 8. Compressive strength for $400 \mathrm{~mm} \mathrm{1:2:4 \text {pavingstone }}$

\begin{tabular}{lcccc}
\hline \multirow{2}{*}{$\begin{array}{l}\text { Polypropylene } \\
\text { Composition (\%) }\end{array}$} & \multicolumn{4}{c}{ Compressive Strengths $\left(\mathbf{N} / \mathbf{m m}^{\mathbf{2}}\right)$} \\
\cline { 2 - 5 } 10 & $\mathbf{7}$ days & 14 Days & 21 Days & 17.37 \\
8 & 10.53 & 14.50 & 16.97 & 27.36 \\
6 & 10.03 & 14.49 & 15.77 & 26.23 \\
4 & 9.27 & 14.08 & 15.13 & 25.76 \\
2 & 9.23 & 13.78 & 14.87 & 25.26 \\
0 & 8.80 & 13.70 & 14.70 & 25.20 \\
\hline
\end{tabular}

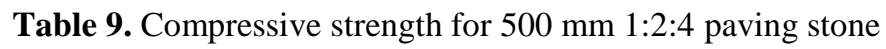

\begin{tabular}{lcccc}
\hline Polypropylene & \multicolumn{4}{c}{ Compressive Strengths $\left(\mathbf{N} / \mathbf{m m}^{\mathbf{2}}\right)$} \\
\cline { 2 - 5 } Composition $(\%)$ & $\mathbf{7}$ days & $\mathbf{1 4}$ Days & 21 Days & 28 Days \\
\hline 10 & 10.93 & 15.02 & 18.00 & 26.27 \\
8 & 9.30 & 14.87 & 17.83 & 25.27 \\
6 & 8.63 & 14.68 & 17.23 & 24.39 \\
4 & 8.37 & 14.61 & 17.10 & 24.33 \\
2 & 8.17 & 14.54 & 16.00 & 24.30 \\
0 & 7.97 & 14.51 & 15.33 & 24.01 \\
\hline
\end{tabular}

Table 10. Compressive strength for $200 \mathrm{~mm}, 400 \mathrm{~mm}$ and $500 \mathrm{~mm}$ 1:3:6 paving stone

\begin{tabular}{lccc}
\hline Polypropylene Composition & \multicolumn{3}{c}{ Compressive Strengths at 28 days $\left(\mathbf{N} / \mathbf{m m}^{\mathbf{2}}\right)$} \\
\cline { 2 - 4 }$(\boldsymbol{\%})$ & $\mathbf{2 0 0} \mathbf{~ m m}$ & $\mathbf{4 0 0} \mathbf{~ m m}$ & $\mathbf{5 0 0} \mathbf{~ m m}$ \\
\hline 10 & 17.70 & 17.10 & 16.77 \\
8 & 17.16 & 16.23 & 16.33 \\
6 & 16.87 & 15.70 & 15.17 \\
4 & 15.87 & 14.70 & 14.77 \\
2 & 15.10 & 14.23 & 14.43 \\
0 & 14.77 & 13.73 & 14.03 \\
\hline
\end{tabular}


Table 11. Flexural strength for $200 \mathrm{~mm}, 400 \mathrm{~mm}$ and $500 \mathrm{~mm}$ 1:3:6 paving stone

\begin{tabular}{lccc}
\hline $\begin{array}{l}\text { Polypropylene Composition } \\
(\%)\end{array}$ & \multicolumn{3}{c}{ Flexural Strengths at $\mathbf{1 4}$ days $\left(\mathbf{N} / \mathbf{m m}^{\mathbf{2}}\right)$} \\
\cline { 2 - 4 } & $\mathbf{2 0 0} \mathbf{~} \mathbf{m}$ & $\mathbf{4 0 0} \mathbf{~ m m}$ & $\mathbf{5 0 0} \mathbf{~ m m}$ \\
\hline 10 & 7.50 & 5.64 & 5.05 \\
8 & 6.86 & 5.25 & 4.76 \\
6 & 6.56 & 4.80 & 4.49 \\
4 & 6.00 & 4.65 & 4.24 \\
2 & 5.86 & 4.46 & 4.17 \\
0 & 5.54 & 4.14 & 4.14 \\
\hline
\end{tabular}

Table 12. Flexural strength for $200 \mathrm{~mm}, 400 \mathrm{~mm}$ and $500 \mathrm{~mm}$ 1:3:6 paving stone

\begin{tabular}{lccc}
\hline $\begin{array}{l}\text { Polypropylene Composition } \\
(\%)\end{array}$ & \multicolumn{3}{c}{ Flexural Strengths at $\mathbf{2 8}$ days $\left(\mathbf{N} / \mathbf{m m}^{\mathbf{2}}\right)$} \\
\cline { 2 - 4 } & $\mathbf{2 0 0} \mathbf{~ m m}$ & $\mathbf{4 0 0} \mathbf{~ m m}$ & $\mathbf{5 0 0} \mathbf{~ m m}$ \\
\hline 10 & 12.90 & 9.60 & 8.10 \\
8 & 12.90 & 9.43 & 7.37 \\
6 & 11.57 & 9.13 & 6.80 \\
4 & 10.93 & 8.97 & 6.30 \\
2 & 10.67 & 8.33 & 5.23 \\
0 & 10.03 & 7.93 & 4.83 \\
\hline
\end{tabular}

\section{Compression-flexural strength relationship}

The comparison between the compressive Strengths and the rupture modulus (flexural strengths) of the 200 $\mathrm{mm}$ 1:2:4 concrete with different percentage polypropylene composition can be seen in Figure 2.

The relationship between the compressive strength (independent variable) based on BS EN 12390-3:2019 standard to the flexural strength (dependent variable) based on the BS EN 12390-5:2019 yielded a correlation coefficient $(r)$ of 0.92 and this regression is statistically significant at 95 percent confidence level. From this

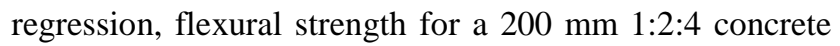
can be predicted from compressive strength using equation 1 .

$\mathrm{y}=1.4136 \mathrm{x}-23.704$

where

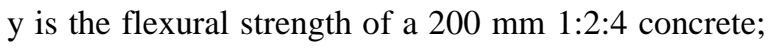
and

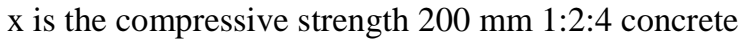

Similarly, the comparison between the compressive strengths and flexural strengths of the $400 \mathrm{~mm} \mathrm{1:2:4}$ concrete with different percentage polypropylene composition is presented in Figure 3. The relationship between the compressive strength and the flexural strength yielded a correlation coefficient $(r)$ of 0.89 and this regression is statistically significant at 95 percent confidence level.
Form the analysis, the flexural strength for a $400 \mathrm{~mm}$ 1:2:4 concrete can be predicted from compressive strength using equation 2 .

$\mathrm{y}=0.5928 \mathrm{x}-6.3554$

where

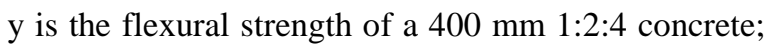
and

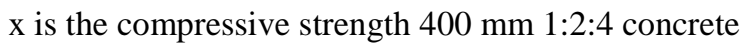

Furthermore, the comparison between the compressive strengths and the rupture modulus of the 500 $\mathrm{mm}$ 1:2:4 concrete with different percentage polypropylene composition in Figure 4 yielded a correlation coefficient $(r)$ of 0.88 and this regression is statistically significant at 95 percent confidence level.

Form the regression analysis, the flexural strength for a $500 \mathrm{~mm}$ 1:2:4 concrete can be predicted from Compressive strength using equation 3 .

$\mathrm{y}=1.2849 \mathrm{x}-25.37$

where $\mathrm{y}$ is the flexural strength of a $500 \mathrm{~mm} \mathrm{1:2:4}$ concrete;

and

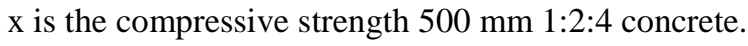




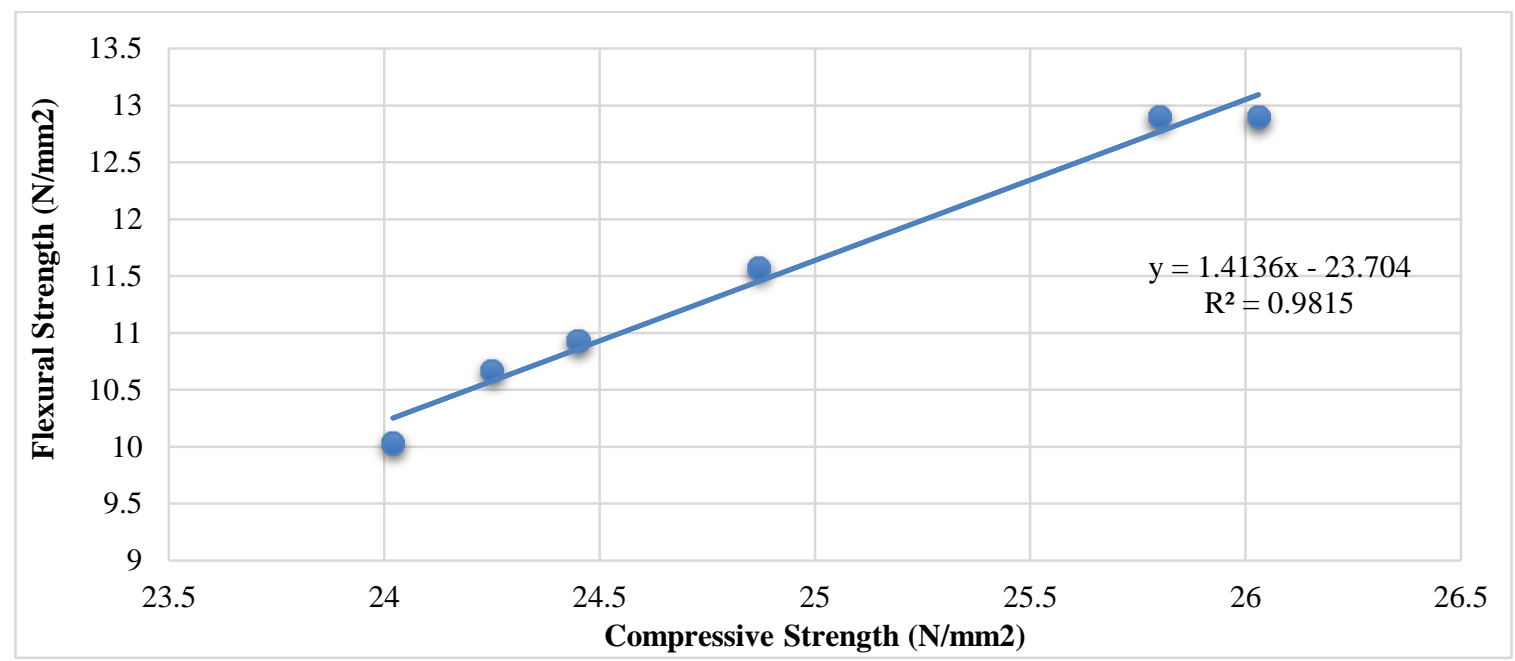

Figure 2. Flexural-compression strengths correlation diagram for $200 \mathrm{~mm} \mathrm{1:2:4} \mathrm{concrete}$

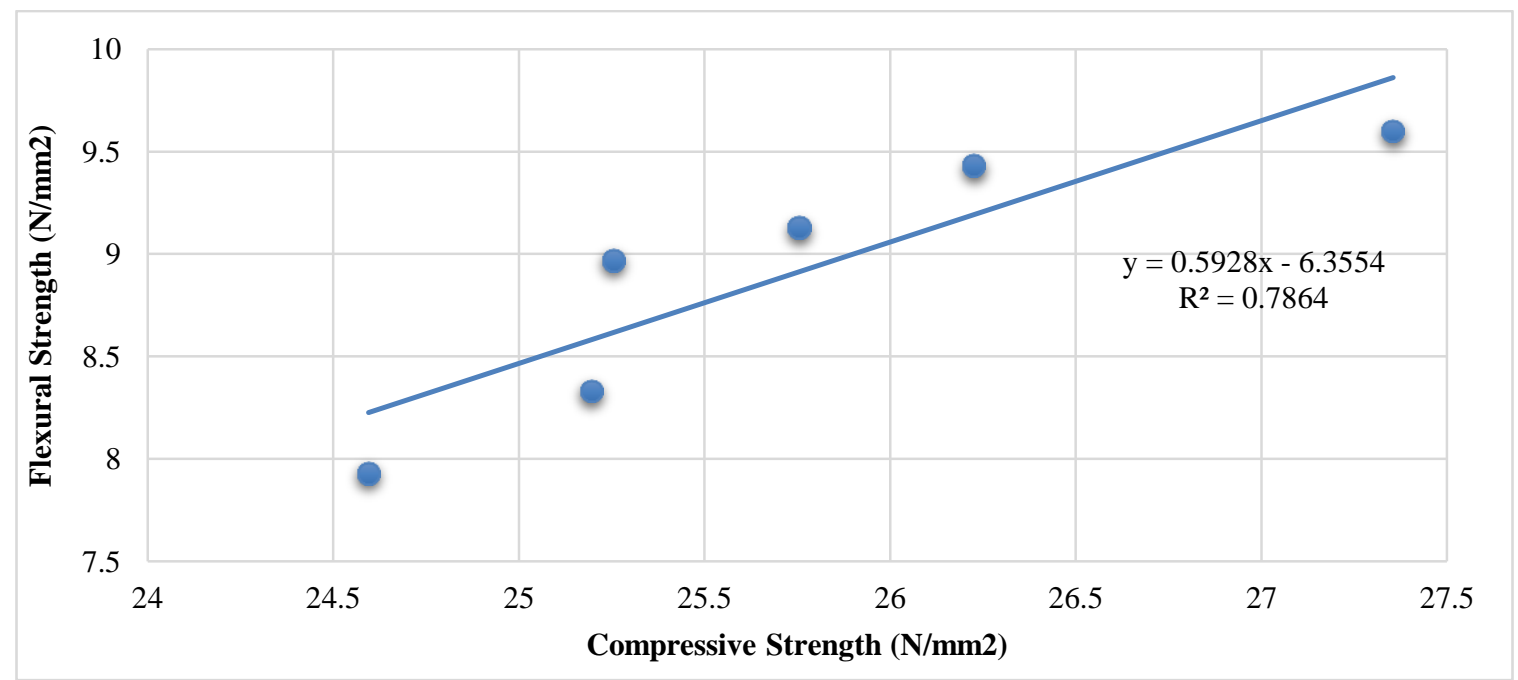

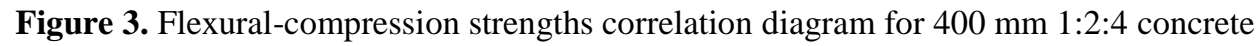

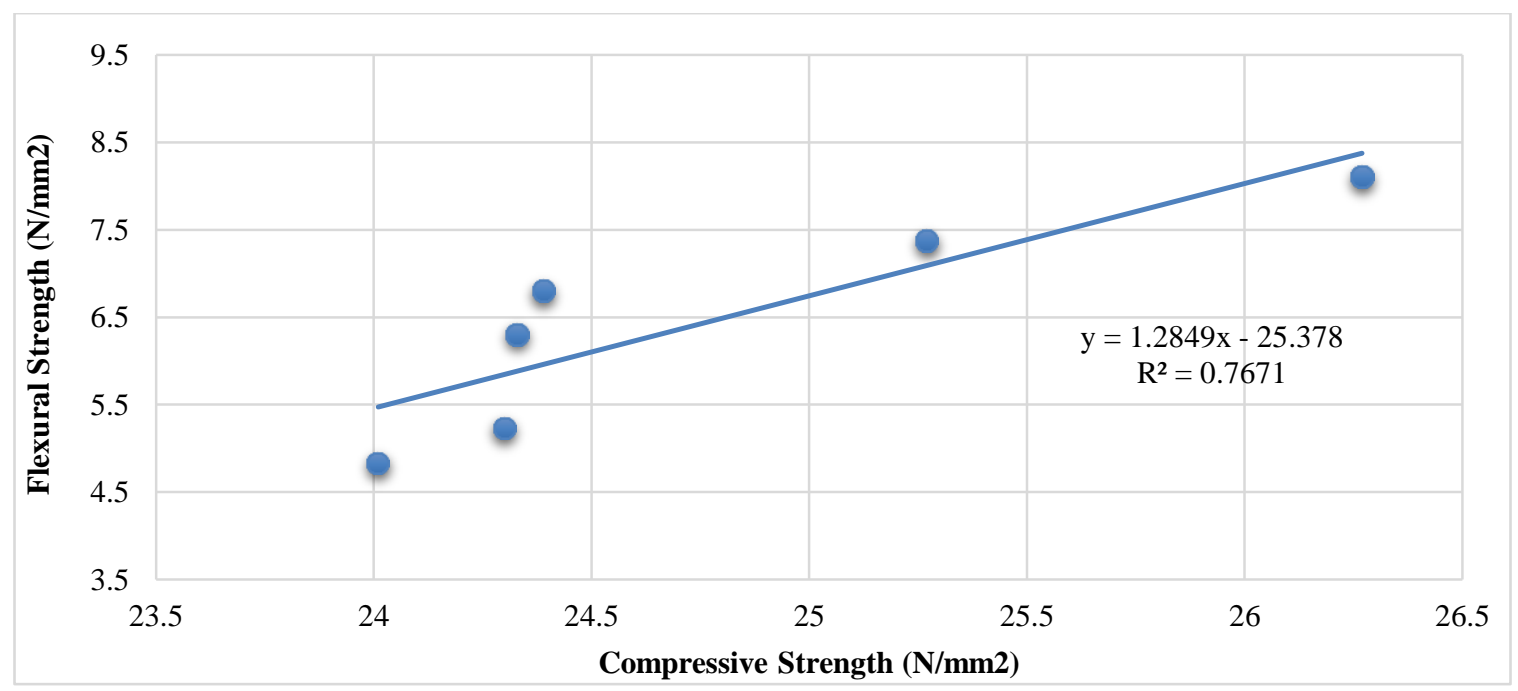

Figure 4. Flexural-compression strengths correlation diagram for $500 \mathrm{~mm} \mathrm{1:2:4} \mathrm{concrete}$ 


\section{CONCLUSION}

This research has focused on the use of polypropylene based waste chair in different percentage compositions to modify $1: 2: 4$ and 1:3:6 grades of concrete used to produce paving stones of different lengths $(200 \mathrm{~mm}, 400 \mathrm{~mm}$ and $500 \mathrm{~mm}$ ) for pavement construction. Strength tests like compressive and flexural tests have been performed to determine the strength characteristics and the correlation of these strengths. Other tests to determine the suitability of the aggregates and fresh concretes for use in the production of concrete paving stones have also been carried out.

Form this research, the highest compressive strength obtained for the $200 \mathrm{~mm}, 400 \mathrm{~mm}$ and $500 \mathrm{~mm}$ lengths paving stones are respectively $26.03 \mathrm{~N} / \mathrm{mm}^{2}, 27.36 \mathrm{~N} / \mathrm{mm}^{2}$ and $26.27 \mathrm{~N} / \mathrm{mm}^{2}$ after 28 days of curing for 1:2:4 concrete at $10 \%$ polypropylene composition. However,

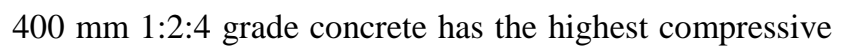
strength of $27.36 \mathrm{~N} / \mathrm{mm}^{2}$ at $10 \%$ polypropylene composition. Furthermore, the compressive strengths of

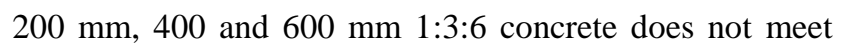
the requirement of $20 \mathrm{~N} / \mathrm{mm}^{2}$ for 28 days to open the concrete pavement for traffic. Therefore 1:3:6 concrete is not good under any condition for producing concrete for paving stones.

The 14 days flexural strength criteria of $4.1 \mathrm{~N} / \mathrm{mm}^{2}$ (600 psi) required to open pavement to traffic and the flexural strength design critreria of mean 28-day flexural strength of $4.5 \mathrm{~N} / \mathrm{mm}^{2}$ were met by the flexural strengths all lengths and percentage compositions, while the highest flexural strength obtained after 14 days is $7.50 \mathrm{~N} / \mathrm{mm}^{2}$ at $10 \%$ polypropylene composition for $200 \mathrm{~mm}$ length. Likewise, the $200 \mathrm{~mm}$ long paving stone with $10 \%$ polyprpopylene composition has the highest flexural strength of $12.90 \mathrm{~N} / \mathrm{mm}^{2}$. In effect it can be concluded that the $200 \mathrm{~mm}$ long paving stone at $10 \%$ polypropylene composition is better in the consideration of the length of paving stone that can give an adequate flexural strength which is the most important requirent in concrete pavement requirement.

The correlation coefficients $(r)$ obtained for the compression-flexural strength relationship for $200 \mathrm{~mm}$, $400 \mathrm{~mm}$ and $500 \mathrm{~mm}$ are $0.92,0.88$ and 0.89 respectively further validate the strong positive relationship existing between the compression and flexural strengths of concrete pavement. The $200 \mathrm{mmm}$ at $10 \%$ polypropylene composition correlation coefficient has that the highest value of 0.98 which better explains the compressionflexural strength relationship and validates the $200 \mathrm{~mm}$ length at $10 \%$ polypropylene composition paving stone as the most adequate length of paving stone for pavement construction.

\section{DECLARATIONS}

\section{Authors' contribution}

Olugbenga Joseph Oyedepo designed the experimental plan, Ebenezer Omoniyi Olukanni carried out the laboratory tests and Temitope Rufai Arowolo did analysis of results and the write up

\section{Conflict of interest}

There is no conflict of interest with any third party.

\section{REFERENCES}

Bhardwaj A, Tomar RK, Duggal P, Singh A, Singh DP, Bajaj I. (2020). Plastic used in flexible pavements: Retrospects and prospects. In 2020 International Conference on Intelligent Engineering and Management (ICIEM) 2020 Jun 17 (pp. 183-186).

IEEE. DOI: https://doi.org/10.1109/ICIEM48762.2020.9160181

BS 812-109 (2020). Testing Aggregate Methods for the Determination of Moisture Content. British Standards Institution, 389 Chiswick High Road, London, www.bsigroup.com

BS EN 1097-2 (2020). Tests for Mechanical and Physical Properties of Aggregates - Method for the Determination of Resistance to Fragmentation. British Standards Institution, 389 Chiswick High Road, London, www.bsigroup.com

BS EN 12350-2 (2019). Testing Fresh Concrete- Slump Test. British Standards Institution, 389 Chiswick High Road, London, www.bsigroup.com

BS EN 12350-4 (2019). Testing Fresh Concrete- Degree of Compatibility. British Standards Institution, 389 Chiswick High Road, London, www.bsigroup.com

BS EN 12390-3 (2019). Testing hardened Concrete Compressive Strength of Test Specimen. British Standards Institution, 389 Chiswick High Road, London, www.bsigroup.com

BS EN 12390-5 (2019). Testing hardened Concrete - Flexural Strength of Test Specimen. British Standards Institution, 389 Chiswick High Road, London, www.bsigroup.com

BS EN 12620+A1 (2008). Aggregates for Concrete. British Standards Institution, 389 Chiswick High Road, London, www.bsigroup.com

BS EN 1338 (2003). Concrete Paving Blocks - Requirements and Test Method. British Standards Institution, 389 Chiswick High Road, London, www.bsigroup.com

BS EN 197-1 (2011). Composition, Specification and Conformity Criteria for Common Cement. British Standards Institution, 389 Chiswick High Road, London, www.bsigroup.com

BS ISO 11277 (2020). Methods for the Determining Particle Size Distribution Applicable to a Wide Range of Mineral Soil. 
British Standards Institution, 389 Chiswick High Road, London, www.bsigroup.com

EPA (2015). Summary of Expert Discussion Forum on Possible Human Health Risks from Microplastics in the Marine Environment, Environmental Protection Agency (EPA). https://www.epa.gov/sites/production/files/2015-

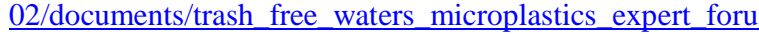
m meeting summary 2-6-15.pdf

Huang Y, Bird RN, Heidrich O (2007). A review of the use of recycled solid waste materials in asphalt pavements. Resources, conservation and recycling. 52(1): 58-73. DOI: https://doi.org/10.1016/j.resconrec.2007.02.002

Jambeck J, Hardesty BD, Brooks AL, Friend T, Teleki K, Fabres J, Beaudoin Y, Bamba A, Francis J, Ribbink AJ, Baleta T. (2018). Challenges and emerging solutions to the land-based plastic waste issue in Africa. Marine Policy. 96:256-63. DOI: https://doi.org/10.1016/j.marpol.2017.10.041

Lazarevic D, Aoustin E, Buclet N and Brandt N. (2010). Plastic waste management in the context of a European recycling society: comparing results and uncertainties in a life cycle perspective. Resour. Conserv. Recycl., Volume 55, pp. 246259. DOI: https://doi.org/10.1016/j.resconrec.2010.09.014

Ramadhansyah PJ, Mohd Ibrahim MY, Mohd Rosli H, Warid MN, Wan Ibrahim MH (2014). Porous concrete pavement containing nano-silica: Pre-review. Advanced Materials Research. Vol. 911, pp. 454-458. Trans Tech Publications. DOI: https://doi.org/10.4028/www.scientific.net/AMR.911.454

Saberian M, Li J, Kilmartin-Lynch S, and Boroujeni M. (2021). Repurposing of COVID-19 single-use face masks for pavements base/subbase. Science of the Total Environment, 769 , 145527.

DOI: https://doi.org/10.1016/j.scitotenv.2021.145527

Shah DS and Pitroda J. (2013). Assessment for use of gravel in pervious concrete. Int. J. Eng. Trend. Technol., 4(10), pp. 4306-4310. http://www.ijettjournal.org

Singh P and Sharma VP (2016). Integrated plastic waste management: environmental and improved health approaches. Procedia Environ. Sci, Volume 35, p. 692-700. DOI: https://doi.org/10.1016/j.proenv.2016.07.068 